\title{
島根県岡見深成岩体中の塩基性包有岩亡花崗岩質“隐捕獲岩”の成因*
}

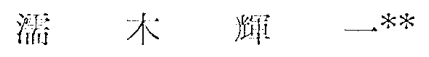 \\ (1956 维 10 月 15 日棌理)
}

\section{Genesis of Some Basic Inclusions and Granitic "Pseudo-Xenoliths" found in the Okami Plutonic Complex, Shimane Prefecture}

Terukazu NuREKI

(Abstract)

In the Okami plutonic complex, consisting of biotite-hornblende-quartz-diorite, hornblendebiotite-granodiorite and hornblende-biotite-granite, the writer found some interesting basic inclusions which are the products of granitization. The larger part of the complex is occupied by hornblende-biotite-granodiorite, in which. two types of inclusions are abundantly found. The one type is a basic, fine-grained and relatively homogeneous variety (type I) and the other is basic, relatively coarse-grained, and rather heterogeneous (type II). At the marginal zone of the thermally-metamorphosed quartz-diorite, where the granite comes into contact with it, many granitic "pseudo-xenoliths," namely angular to sub-angular granitic patches with sharp boundary, can be found.

This paper mainly deals with the metamorphic features of these inclusions and the genesis of the granitic pseudo-xenoliths.

The genesis of the granitized inclusions of type I may be attributed to the addition of salic components (sodic plagioclase, quartz and potash-feldspar) to the porphyrite inclusions with simultaneous subtraction of mafic components from the inclusions, while the inclusions of type II and the granitic pseudo-xenoliths might be formed by some similar process from quartz-diorite.
I. 安元 $か ゙$ き

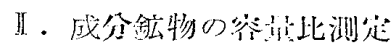
III. 地贸赫よど界不のまらまし

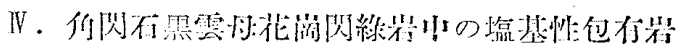

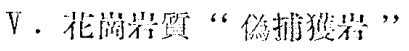
V.

\section{I.まえがき}

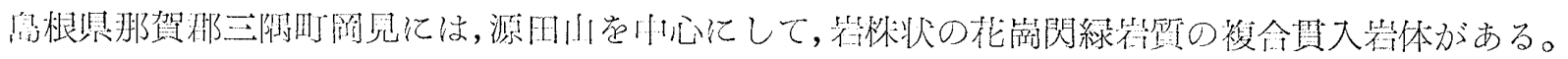

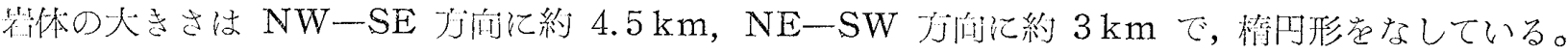

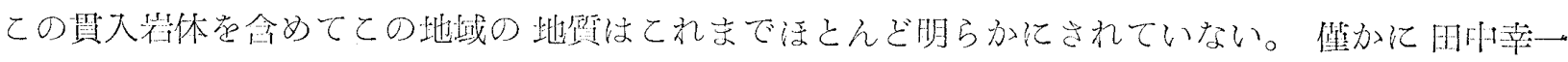

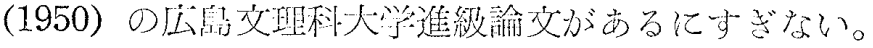

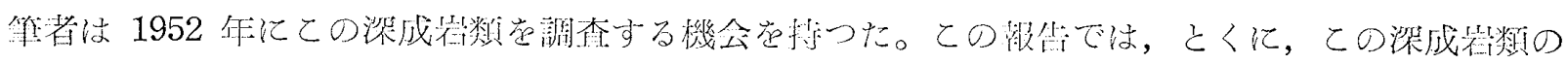

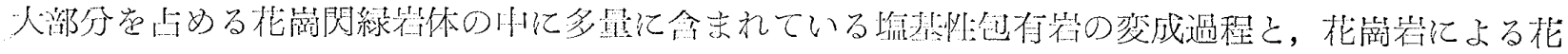

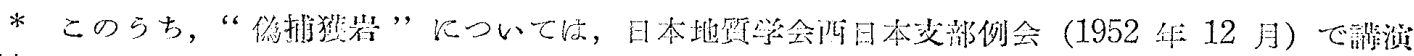

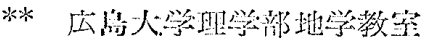

地筑学篗誌 第 63 潜 符 735 号 1957 年 1 月
} 
崗岩化作用の一例としての“偽捕獲岩”の形成過程について考察してみたいと思う。

ての研究にあたつて, 野外ならびに研究室で終始御指導いただいた小島丈㳊授に対し，愿く感謝 の意を表する。また，ての研究に対して多くの有益な助言を与えて下さつた広島大学理学部地学教室 の方々にも深く感謝するしだいである。

\section{II. 成分鉱物の容量比測定}

本報答で朋いた成分鉱物の容量比测定は Leiz の Intergrationstisch によつた。走查線の間隔は $1 \mathrm{~mm}$, 測

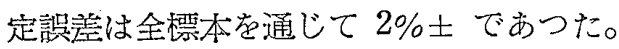

i）測定した標本の虫には色々な粒度の岩不が含まれているので，それらを测定するばあいの薄片の最小有效 面積は岩石の粒度によつて当然異なるわけである。そてで, 花崗岩・花南聞緑岩・不英閃緑岩 (平均粒度：0.35〜 $0.85 \mathrm{~mm}$ )では $6 \mathrm{~cm}^{2}$ で，また包有岩その他の比较的細粒な岩石（平均粒度：0.15〜0.30 $\mathrm{mm}$ ) のばあいは $4 \mathrm{~cm}^{2}$ としだ。

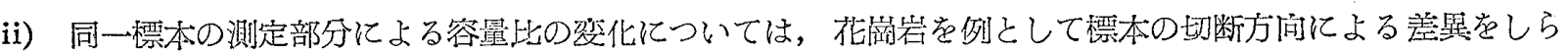
べた。ての花南岩には全く方间性がないので，旗片は，任意方间にまず 1 枚，てれから $7 \mathrm{~cm}$ 離してそれに平行 に 1 枚，乙れら 2 枚に直觕で，しかも相互に淔任な溥片を 2 枚，さらにいずれにも斜交する溥片を 1 枚，誩 5 枚

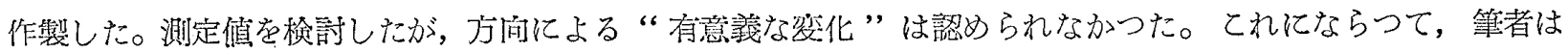

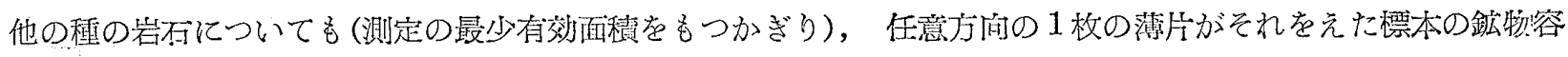
量比安代表するものと仮定した。

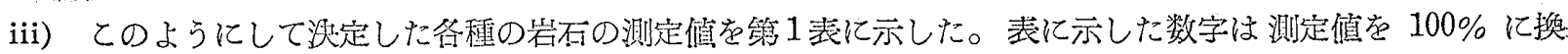
算し，四捨五入してえたものである。

\section{III. 地質および岩石のあらまし}

この地域を構成する宕類は，大別して次の 3 グループにわけられる（第 1 図および第 2 図参照）。

（1）三郡変成吡類（シアー粘板宕・準片岩）

(2) 玢䇹，石英斑岩扔子び閃緑环岩

(3) 深成岩類（岡見澡成岩類と仅称する)

\section{1. 岡見深成岩体の周縁の岩石}

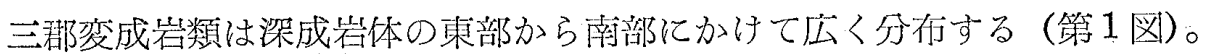

玢岩および玟岩は㳭成岩体の西部および南部に分行しており，また钼音崎でも見いだされる。石策

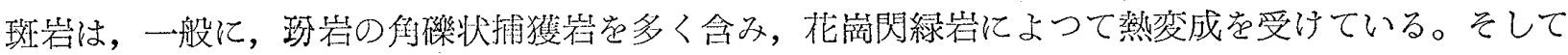
観音崎では花崗岩のルーフ・ペンダント状に産する。閃緑玢岩は本地域ではでく小規模で，石英閃緑

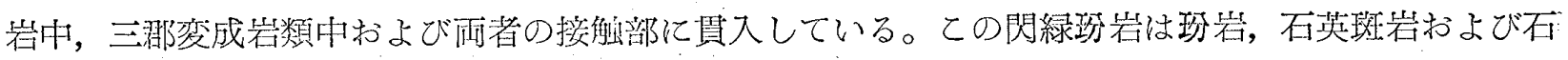

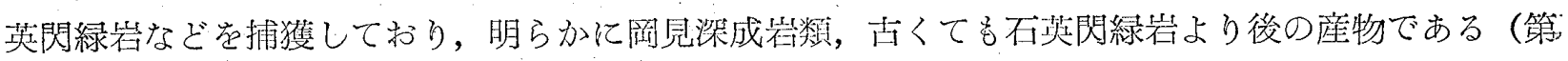
2 図)。

\section{2. 岡見深成岩類}

i) 構成と貫入時期

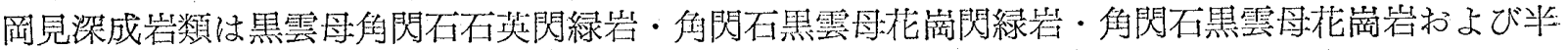
花崗岩からなつている。野外における各岩体相互の関係汃ら，てれらは塩基性から酸性へと順次に貫 大したものとみなされる。順次といつても, 石英閃緑岩と花崗閃緑岩との間には時間的間陌が明らか

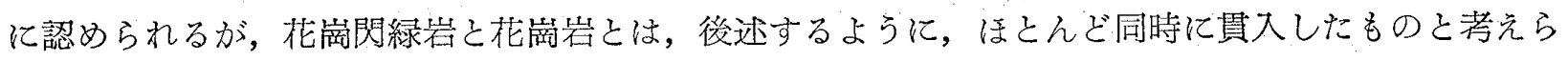
れる。 

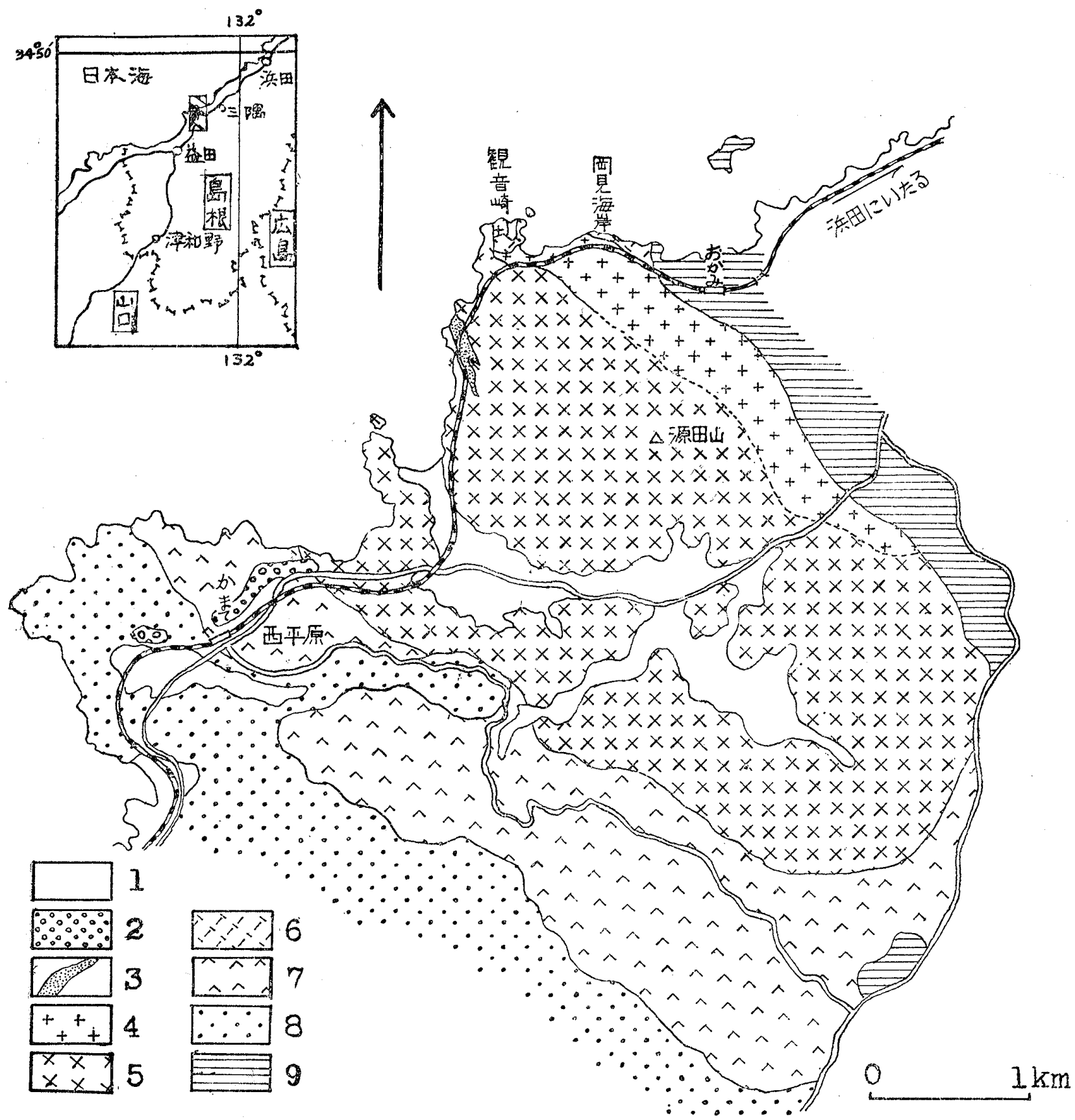

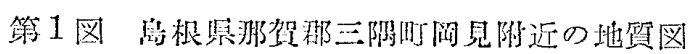

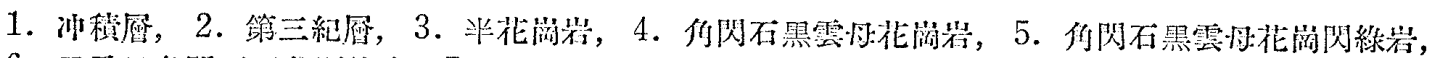

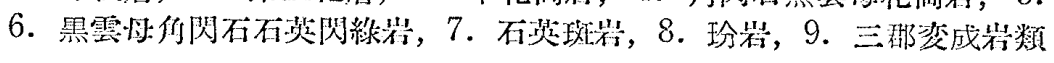

てれらの宕類が貫入した時代については，本地域からは正碓なきめてになる資料がえられない。し

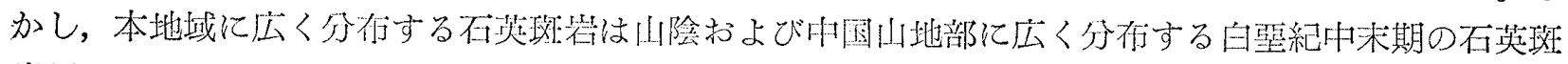

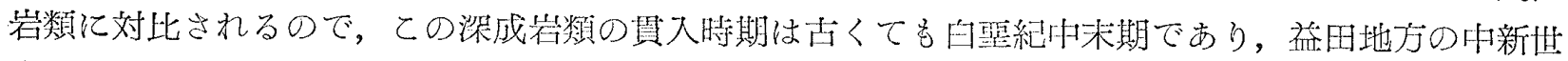
中部層（田中，1950）の惟積以冏であると考えられる*。

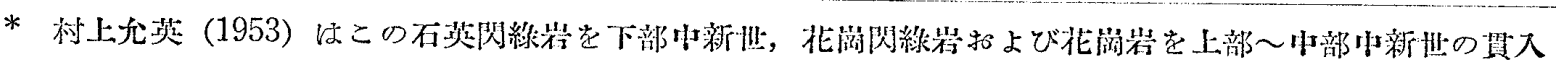

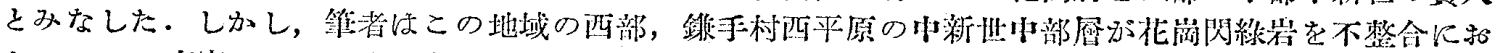

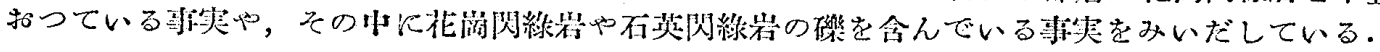




\section{ii）熱変成石英閃緑岩}

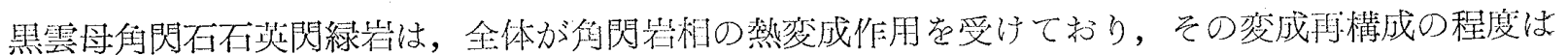
岡見海啋におけるよりも钼音崎における万が高い。

\section{iii）角閃石黒雲母花崗閃緑岩}

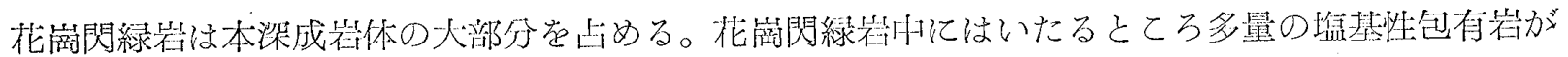

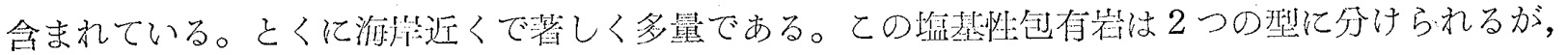
包有岩については後に䛨しくのべる。

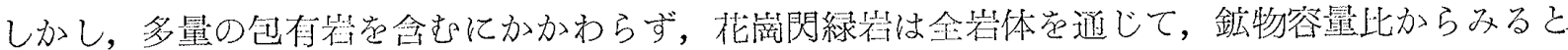
かなり均筫である(符 3 四)。包有岩の近くで鉱物容量比の变化がわずかにみられるが，因眼ではての

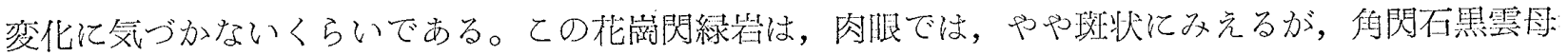
花藏皆にきわ邓てよく似ている。

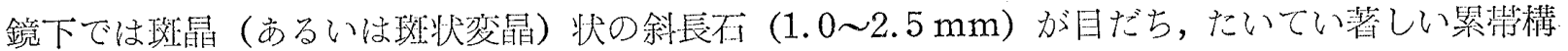

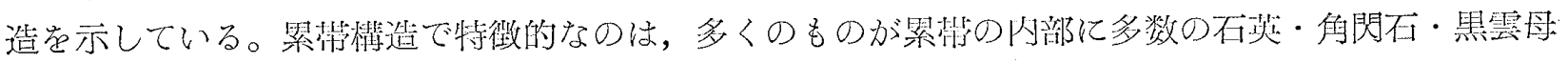

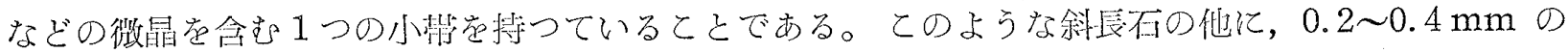

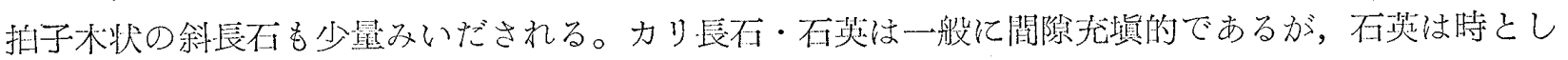

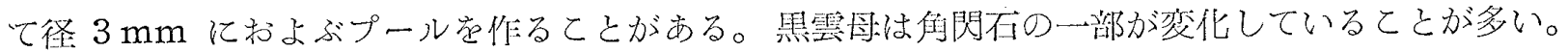

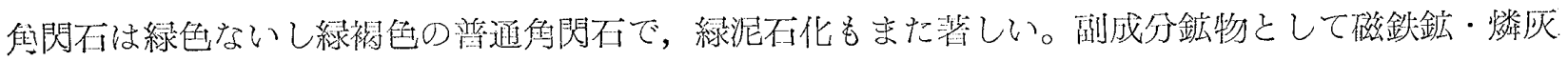
石・ジルコンがある。

\section{iv）角閃石黒雲母花崗岩}

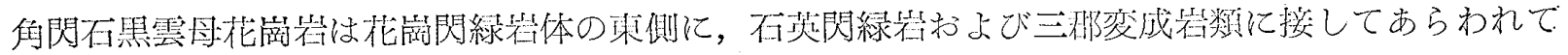

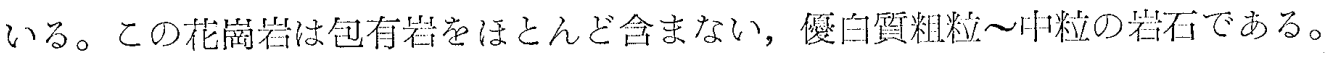

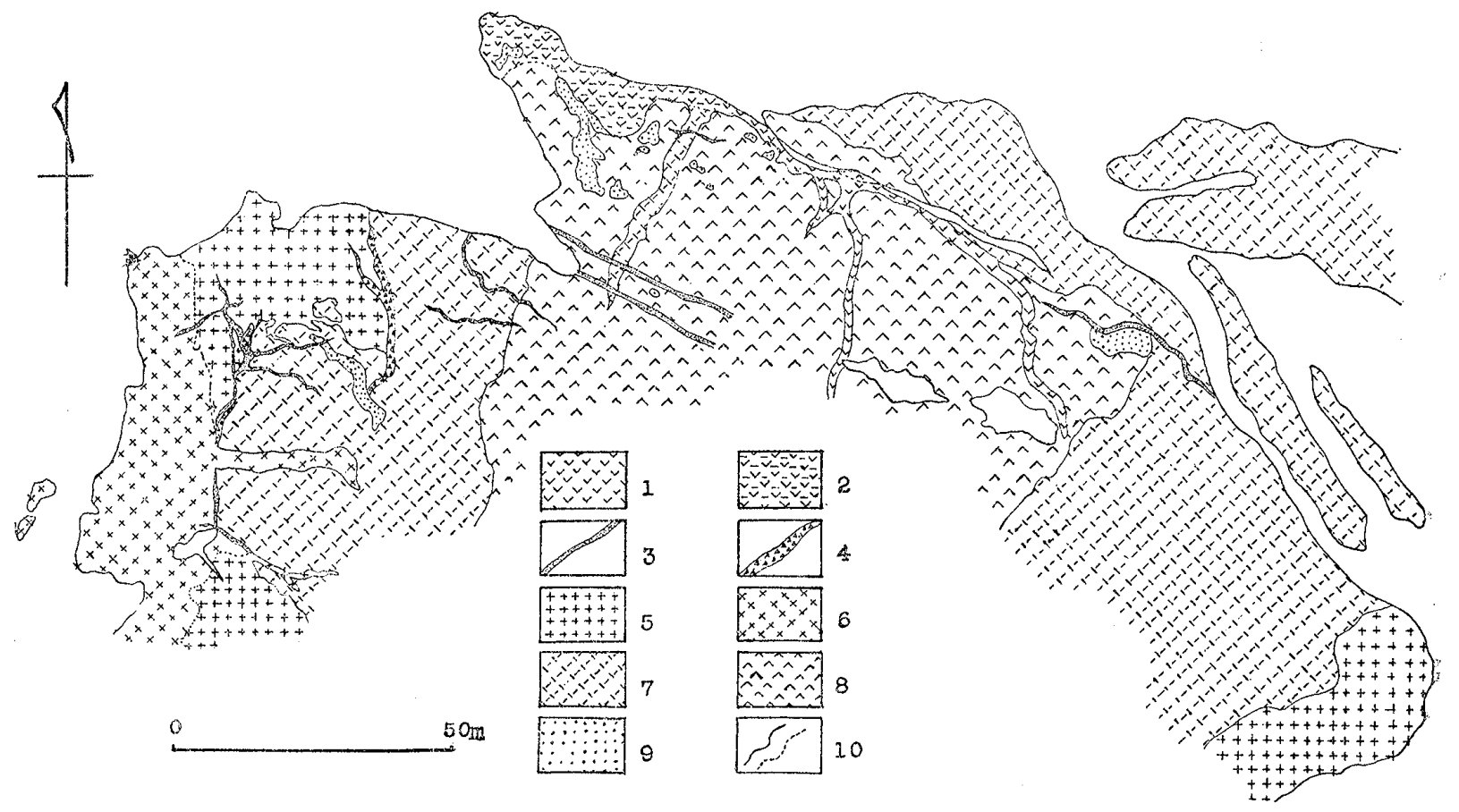

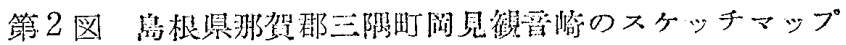

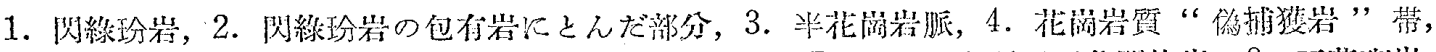

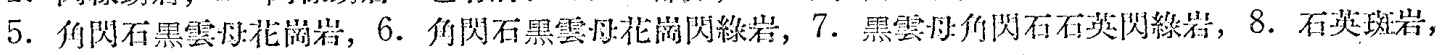

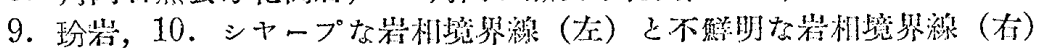




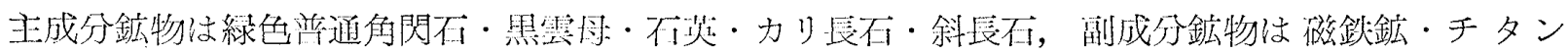

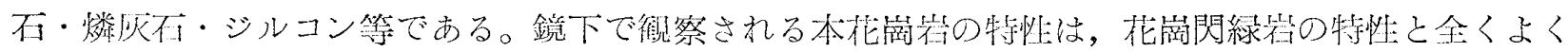
似ている。

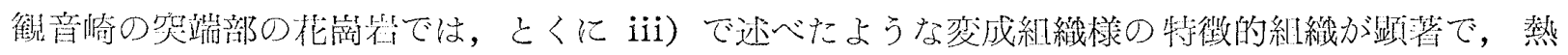

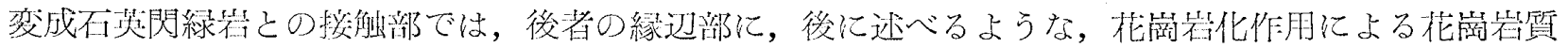

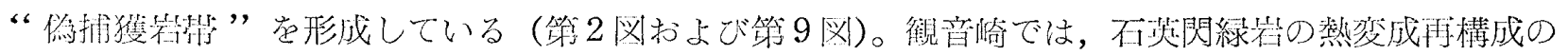

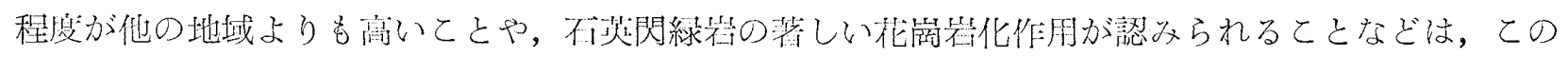

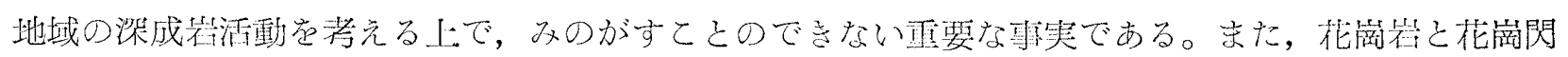

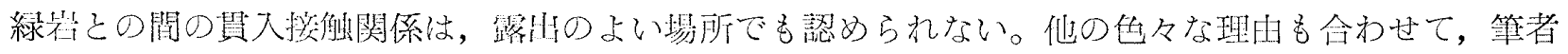

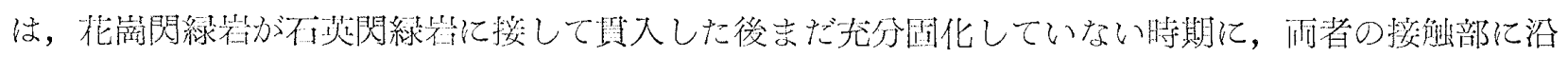

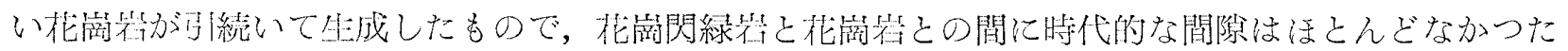
ものと考えている。

\section{v) 半花崗岩}

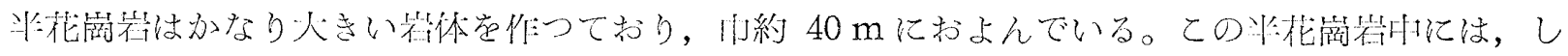

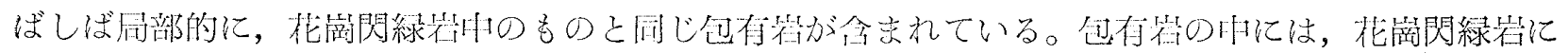

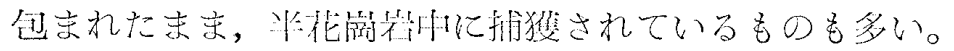

\section{IV. 角閃石黒雲母花崗閃緑岩中の塩基性包有岩}

\section{1. 産状}

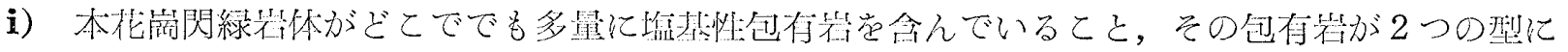

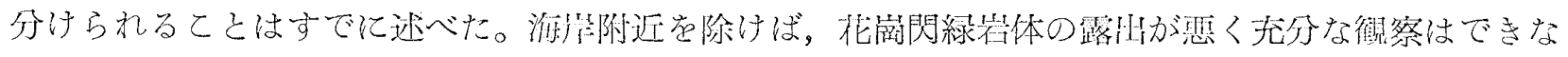

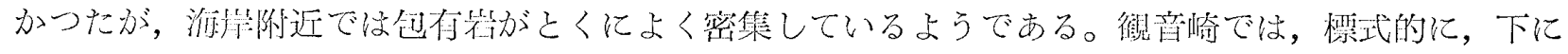

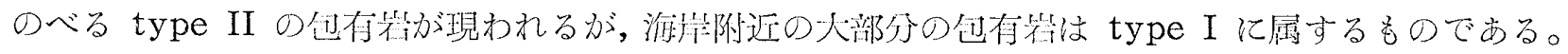

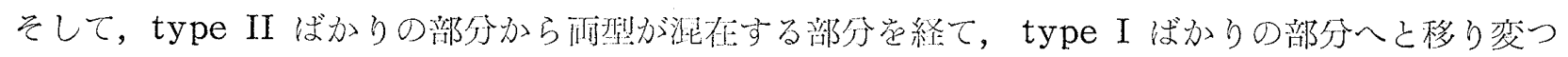

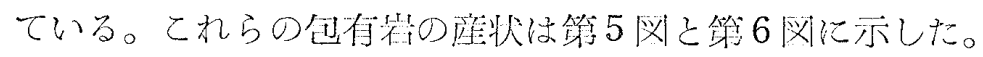

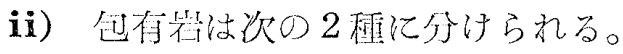

A. 縕䊉で主とんど均賴なもの（type I）(第7网)

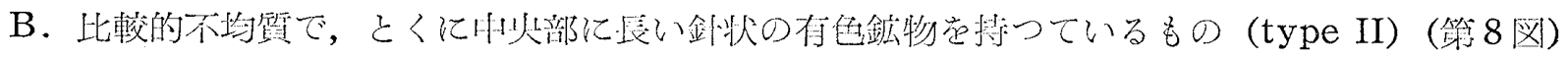
(以下それぞれ type I, type II と绦称する)

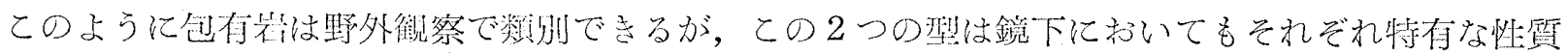

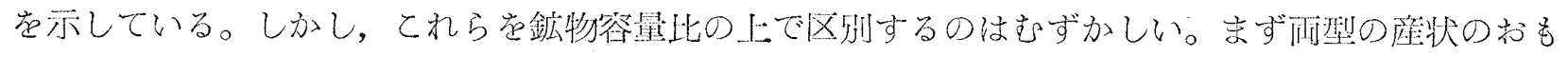

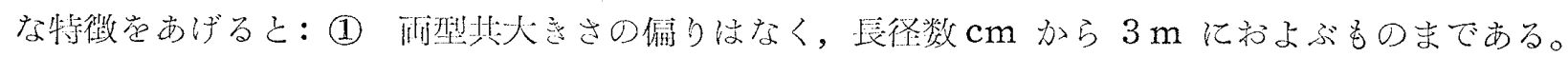

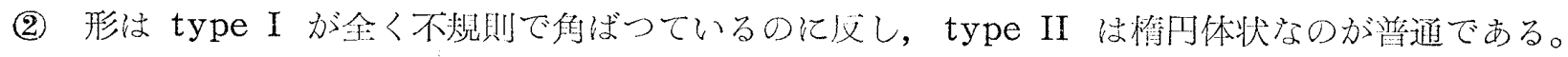

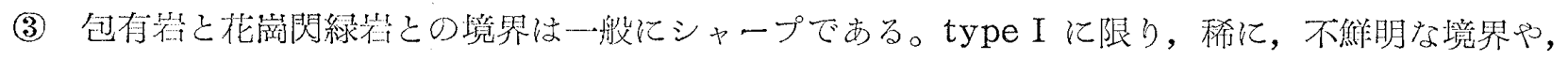

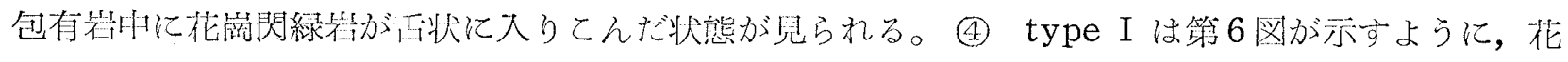

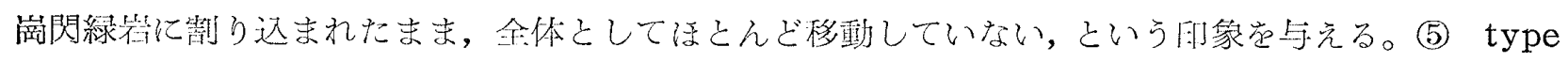

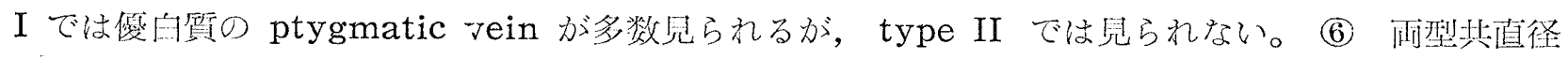

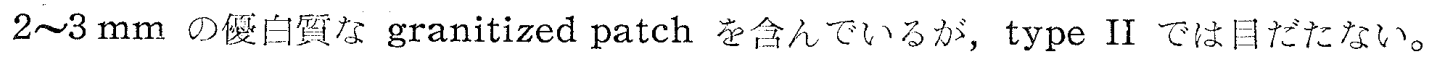

\section{2。両種の包有岩にみられる変成現象 \\ i）細粒でほとんど均質なもの（type I)}


第 1 表 各種の岩石の容量分析值

\begin{tabular}{|c|c|c|c|c|c|c|c|c|c|c|}
\hline & plag. & $\mathrm{K}$-feld. & quartz & biot. & hornb. & opaq. & epid. & chlor. & a11 salics & $\begin{array}{c}\text { all } \\
\text { mafics }\end{array}$ \\
\hline $\begin{array}{r}1 \\
2 \\
3 \\
4 \\
5 \\
6 \\
7 \\
8 \\
9 \\
10 \\
11 \\
12\end{array}$ & $\begin{array}{l}46.4 \\
48.0 \\
47.8 \\
45.1 \\
45.4 \\
42.8 \\
41.7 \\
43.1 \\
47.6 \\
53.4 \\
43.6 \\
46.2\end{array}$ & $\begin{array}{l}22.6 \\
21.6 \\
20.7 \\
23.6 \\
21.7 \\
23.8 \\
22.6 \\
21.6 \\
20.4 \\
16.7 \\
21.2 \\
21.5\end{array}$ & $\begin{array}{l}23.4 \\
23.9 \\
23.4 \\
24.8 \\
25.5 \\
26.3 \\
26.7 \\
27.2 \\
23.0 \\
24.4 \\
31.6 \\
27.0\end{array}$ & $\begin{array}{l}3.4 \\
2.7 \\
2.2 \\
2.7 \\
3.2 \\
4.0 \\
6.0 \\
0.6 \\
3.6 \\
5.3 \\
2.2 \\
2.1\end{array}$ & $\begin{array}{l}3.2 \\
3.3 \\
4.7 \\
3.1 \\
3.2 \\
1.9 \\
2.6 \\
-\overline{3.0} \\
0 . \overline{0} \\
1.9\end{array}$ & $\begin{array}{l}1.0 \\
0.5 \\
1.2 \\
0.7 \\
1.0 \\
1.2 \\
0.4 \\
1.1 \\
1.5 \\
0.2 \\
0.6 \\
1.0\end{array}$ & $\begin{array}{l}= \\
\bar{Z} \\
\overline{-} \\
\bar{E} \\
2.3 \\
0.2 \\
\overline{0.2} \\
0.2\end{array}$ & $\begin{array}{l}\bar{Z} \\
\overline{ } \\
\overline{-} \\
\overline{-} \\
4.1 \\
0.7 \\
\overline{0.1} \\
0.1\end{array}$ & $\begin{array}{l}92.4 \\
93.5 \\
91.9 \\
93.5 \\
92.6 \\
92.9 \\
91.0 \\
91.9 \\
91.0 \\
94.5 \\
96.4 \\
94.7\end{array}$ & $\begin{array}{l}7.0 \\
6.5 \\
8.1 \\
6.5 \\
7.4 \\
7.1 \\
9.0 \\
8.1 \\
9.0 \\
5.5 \\
3.6 \\
5.3\end{array}$ \\
\hline $\begin{array}{l}13 \\
14 \\
15 \\
16 \\
17\end{array}$ & $\begin{array}{l}53.5 \\
56.8 \\
58.4 \\
56.3 \\
66.2\end{array}$ & $\begin{array}{l}7.9 \\
8.3 \\
6.3 \\
7.8 \\
4.5\end{array}$ & $\begin{array}{l}32.1 \\
27.8 \\
27.3 \\
28.6 \\
21.7\end{array}$ & $\begin{array}{l}4.3 \\
2.3 \\
3.9 \\
3.5 \\
0.4\end{array}$ & $\begin{array}{l}0.4 \\
0.6 \\
1.8 \\
2.0 \\
0.5\end{array}$ & $\begin{array}{l}1.2 \\
1.1 \\
1.2 \\
0.9 \\
0.8\end{array}$ & $\begin{array}{l}0.1 \\
0.2 \\
0.3 \\
0.2 \\
1.0\end{array}$ & $\begin{array}{l}0.5 \\
2.9 \\
0.8 \\
0.7 \\
4.9\end{array}$ & $\begin{array}{l}93.5 \\
92.9 \\
92.0 \\
92.7 \\
92.4\end{array}$ & $\begin{array}{l}6.5 \\
7.1 \\
8.0 \\
7.3 \\
7.6\end{array}$ \\
\hline $\begin{array}{l}18 \\
19 \\
20 \\
21 \\
22 \\
23 \\
24\end{array}$ & $\begin{array}{l}56.8 \\
53.3 \\
46.8 \\
62.3 \\
57.6 \\
53.9 \\
55.3\end{array}$ & $\begin{array}{r}8.5 \\
7.4 \\
16.6 \\
4.6 \\
10.2 \\
8.2 \\
10.0\end{array}$ & $\begin{array}{l}24.7 \\
30.2 \\
29.3 \\
22.7 \\
23.0 \\
27.4 \\
26.2\end{array}$ & $\begin{array}{l}5.7 \\
3.1 \\
2.8 \\
3.5 \\
2.8 \\
3.3 \\
2.5\end{array}$ & $\begin{array}{l}2.4 \\
1.7 \\
1.4 \\
3.2 \\
3.3 \\
4.2 \\
1.9\end{array}$ & $\begin{array}{l}1.0 \\
0.7 \\
0.9 \\
0.9 \\
1.3 \\
1.7 \\
1.0\end{array}$ & $\begin{array}{l}0.1 \\
0.5 \\
0.2 \\
0.1 \\
\overline{0.1} \\
0.2\end{array}$ & $\begin{array}{l}0.8 \\
3.1 \\
2.0 \\
2.7 \\
1.8 \\
1.2 \\
2.9\end{array}$ & $\begin{array}{l}90.0 \\
90.9 \\
92.7 \\
89.6 \\
90.8 \\
89.5 \\
91.5\end{array}$ & $\begin{array}{r}10.0 \\
9.1 \\
7.3 \\
10.4 \\
9.2 \\
10.5 \\
8.5\end{array}$ \\
\hline $\begin{array}{l}25 \\
26 \\
27 \\
28 \\
29 \\
30\end{array}$ & $\begin{array}{l}60.8 \\
61.2 \\
60.6 \\
60.2 \\
61.2 \\
59.5\end{array}$ & $\begin{array}{l}2.6 \\
2.9 \\
2.9 \\
2.1 \\
3.6 \\
3.4\end{array}$ & $\begin{array}{l}15.7 \\
12.6 \\
10.1 \\
15.5 \\
10.8 \\
13.1\end{array}$ & $\begin{array}{l}3.0 \\
2.1 \\
1.9 \\
2.5 \\
3.2 \\
3.4\end{array}$ & $\begin{array}{l}12.3 \\
12.7 \\
19.2 \\
18.3 \\
13.9 \\
15.7\end{array}$ & $\begin{array}{l}1.6 \\
2.7 \\
3.9 \\
1 . \overline{1} \\
0.9\end{array}$ & $\begin{array}{l}0.2 \\
\overline{-} \\
0.2 \\
1.0 \\
0.8\end{array}$ & $\begin{array}{l}3.8 \\
5.8 \\
1.4 \\
1.2 \\
4.0 \\
3.2\end{array}$ & $\begin{array}{l}79.1 \\
76.7 \\
73.6 \\
77.8 \\
76.8 \\
76.0\end{array}$ & $\begin{array}{l}20.9 \\
23.3 \\
26.4 \\
22.2 \\
23.2 \\
24.0\end{array}$ \\
\hline $\begin{array}{l}31 \\
32 \\
33 \\
34 \\
35 \\
36\end{array}$ & $\begin{array}{l}61.3 \\
61.6 \\
64.0 \\
62.2 \\
63.0 \\
64.6\end{array}$ & $\begin{array}{l}2.2 \\
1.9 \\
1.7 \\
1.4 \\
1.3 \\
1.9\end{array}$ & $\begin{array}{l}14.9 \\
17.6 \\
12.0 \\
14.3 \\
15.3 \\
13.6\end{array}$ & $\begin{array}{l}3.3 \\
4.5 \\
3.2 \\
3.8 \\
4.2 \\
3.2\end{array}$ & $\begin{array}{l}15.3 \\
10.5 \\
14.1 \\
13.8 \\
12.4 \\
14.3\end{array}$ & $\begin{array}{l}1.1 \\
2.0 \\
2.7 \\
1.9 \\
2.1 \\
1.0\end{array}$ & $\begin{array}{l}\bar{Z} \\
\overline{-} \\
0.3 \\
0.2\end{array}$ & $\begin{array}{l}1.9 \\
1.9 \\
2.3 \\
1.8 \\
1.4 \\
1.2\end{array}$ & $\begin{array}{l}78.4 \\
81.1 \\
77.7 \\
78.7 \\
79.6 \\
80.1\end{array}$ & $\begin{array}{l}21.6 \\
18.9 \\
22.3 \\
21.3 \\
20.4 \\
19.9\end{array}$ \\
\hline $\begin{array}{l}37 \\
38 \\
39 \\
40 \\
41 \\
42 \\
43\end{array}$ & $\begin{array}{l}63.1 \\
56.8 \\
63.2 \\
52.8 \\
57.3 \\
58.7 \\
57.4\end{array}$ & $\begin{array}{l}3.4 \\
5.1 \\
4.1 \\
6.5 \\
3.1 \\
4.7 \\
6.7\end{array}$ & $\begin{array}{l}17.6 \\
20.8 \\
17.6 \\
31.6 \\
22.9 \\
20.4 \\
28.0\end{array}$ & $\begin{array}{l}8.1 \\
0.8 \\
3.4 \\
2.0 \\
1.4 \\
0.9 \\
0.5\end{array}$ & $\begin{array}{l}6.9 \\
6.0 \\
6.4 \\
1.0 \\
3.6 \\
6.1 \\
0.8\end{array}$ & $\begin{array}{l}0.4 \\
2.0 \\
1.7 \\
1.1 \\
1.1 \\
1.7 \\
1.4\end{array}$ & $\begin{array}{l}0 . \overline{0} \\
0.3 \\
0.6 \\
1.8 \\
0.8 \\
0.3\end{array}$ & $\begin{array}{l}0.5 \\
7.6 \\
3.3 \\
4.4 \\
8.8 \\
6.7 \\
4.9\end{array}$ & $\begin{array}{l}84.1 \\
82.7 \\
84.9 \\
90.9 \\
83.3 \\
83.8 \\
92.1\end{array}$ & $\begin{array}{r}15.9 \\
17.3 \\
15.1 \\
9.1 \\
16.7 \\
16.2 \\
7.9\end{array}$ \\
\hline $\begin{array}{l}44 \\
45 \\
46 \\
47 \\
48 \\
49\end{array}$ & $\begin{array}{l}59.0 \\
60.3 \\
61.0 \\
57.9 \\
59.8 \\
57.5\end{array}$ & $\begin{array}{l}0.6 \\
0.5 \\
0.8 \\
0.9 \\
1.0 \\
1.2\end{array}$ & $\begin{array}{r}10.0 \\
8.9 \\
11.3 \\
8.8 \\
10.4 \\
12.3\end{array}$ & $\begin{array}{l}3.6 \\
3.8 \\
3.3 \\
3.2 \\
4.7 \\
3.9\end{array}$ & $\begin{array}{l}26.4 \\
25.7 \\
22.4 \\
27.8 \\
22.1 \\
22.8\end{array}$ & $\begin{array}{l}0.4 \\
0.5 \\
0.7 \\
0.9 \\
0.8 \\
1.1\end{array}$ & $\begin{array}{l}\overline{0.1} \\
0 . \overline{1} \\
\overline{-} \\
0.3\end{array}$ & $\begin{array}{l}0 . \overline{2} \\
0.4 \\
0.5 \\
1.2 \\
0.9\end{array}$ & $\begin{array}{l}69.6 \\
69.7 \\
73.1 \\
67.6 \\
71.2 \\
71.0\end{array}$ & $\begin{array}{l}30.4 \\
30.3 \\
26.9 \\
32.4 \\
28.8 \\
29.0\end{array}$ \\
\hline $\begin{array}{l}50 \\
51 \\
52 \\
53 \\
54 \\
55\end{array}$ & $\begin{array}{l}58.6 \\
61.3 \\
60.4 \\
59.0 \\
57.0 \\
59.4\end{array}$ & $\begin{array}{l}0.3 \\
2.2 \\
2.0 \\
2.6 \\
0.8 \\
1.3\end{array}$ & $\begin{array}{r}6.7 \\
10.6 \\
13.1 \\
10.0 \\
11.9 \\
10.2\end{array}$ & $\begin{array}{l}6.1 \\
0.9 \\
0.1 \\
2.1 \\
3.3 \\
1.3\end{array}$ & $\begin{array}{l}27.8 \\
22.0 \\
21.5 \\
24.4 \\
23.6 \\
24.2\end{array}$ & $\begin{array}{l}0.5 \\
1.9 \\
2.2 \\
0.9 \\
2.1 \\
1.4\end{array}$ & $\begin{array}{l}\overline{1.1} \\
0.2 \\
0.1 \\
-\end{array}$ & $\begin{array}{l}- \\
\overline{0} \\
0.5 \\
0.9 \\
1.3 \\
2.2\end{array}$ & $\begin{array}{r}65.6 \\
74.1 \\
75.5 \\
71.6 \\
69.7 \\
70.9\end{array}$ & $\begin{array}{l}34.4 \\
25.9 \\
24.5 \\
28.4 \\
30.3 \\
29.1\end{array}$ \\
\hline
\end{tabular}




\begin{tabular}{c|c|c|c|c|c|c|c|c|c|c}
\hline & plag. & K-feld. & quartz & biot. & hornb. & opaq. & epid. & chlor. & all salics & all \\
mafics
\end{tabular}

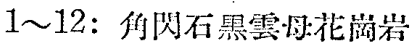

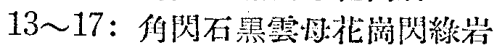

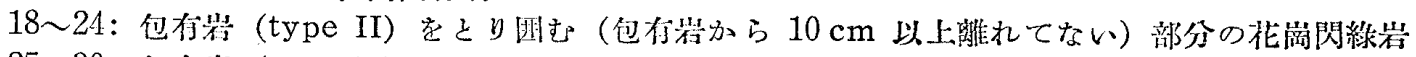

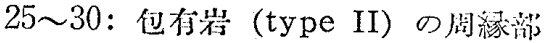
31 36: 包存岩 (type II) の小块部

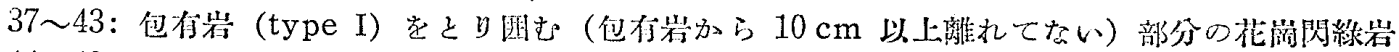
44 49: 包份岩 (type I) の周縁部

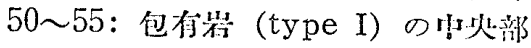

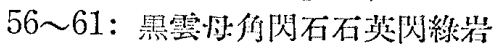
62 66: 玢岩

推音崎および西部海岸の type I には白色の granitized patch がよく発達している。

(a) 镜下では，包有岩の中央部々䧓緣部々で鉱物成分・組織に差異がみいだされない。その組織 は閃緑玢岩様である。鉱物容量比によつても中央部と周縁部とを区別することはできない。

主成分鉱物は斜長石（曹灭長石）・石英・的閃石・黒雲母で，少量のカリ長石者合んでいる。磁鉄 鉱の小晶が普遍的にみられる。斜長岩は柊 0.2 0.4 mm の拍子不状の形をしていて，密集してい る。またところどてろに斑状の斜長石がみられる。不获は機械的花藏岩化過程で注入されたものと考 えられ，斜長石とともに優白質のプール责形成している。てれが肉腿でみられる優白筫の granitized patch である。解閃石は緑褐色の普道角閃不で，不規則な外形をしている。黒雲母に較べると压倒的 飞多い。

(b) 包有岩の縁から $50 \mathrm{~cm}$ 以上離れた花崗閃緑岩怯，本地域の一般の花崗閃緑岩と異ならない。 しかし包有岩に近い（10 cm 以内）部分ではかなりのちがいがみられる。ての部分の成分鉱物は斜長 石（酸性曹死長石〜中性長石）・不英・カリ長石・緑褐色普通角閃石・黒雲母で，少量の磁鉄鉱，で くまれにチタン石・燐灰石点み, 包有岩から離れた部分の花崗閃緑岩によく似ているが, 2 3 mm の主として石英からなるプールが密集しているのが微察される。プールは音通に 斜長石（0.1〜0.4 $\mathrm{mm}$ ) ・鿇閃不の小晶を含んでいる。また長さ $2 \mathrm{~mm} \pm の$ 斑状変晶様の斜長石もみられる。比較的大 きな有色鉱物の結晶は黒雲母である。有色鉱物は緑泥石化が著しい。

こてで注意するべきととは，包有岩をとり团んでいる部分の斜長石の小晶と，包有岩中の斜長石の 小晶とが（全く）同種のものであるといらととと, 包有岩をとり国んでいる花崗閃緑岩怯, 包有岩か らかなり離れた部分の花菵閃緑岩よりも，全 mafic 量に富んでいる（第3図）といらととである。

\section{ii）比較的不均質にみえるもの（type II）}

Type II の特徵は,まず外形が㯐四体状で，少くとも角ばつた形をしていないということと，包有 岩の中央部の有色鉱物が針状の形（数 $\mathrm{mm} \sim 1 \mathrm{~cm}$ ） 它していて，中央部が優白質，周緑部が優黒質 な傾向を示していることである。大きい包有岩ほどての傾向が著しいのは興味あるてとである。大き 


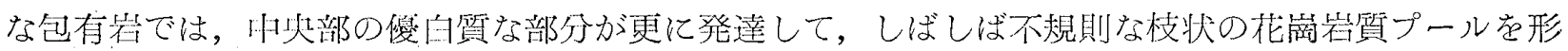
成している。Type I では，包有㞸荲とり四んでいる部分の花崗閃緑岩が包有岩から離れた部分の花 崗閃緑岩に比べて暴なつていたが，type II の場會には，肉腿でも鏡下でも，てのような差買がみら

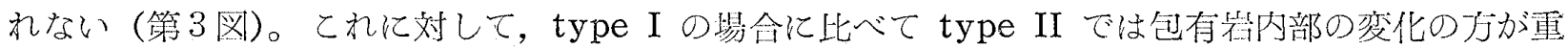
要になつてくる。

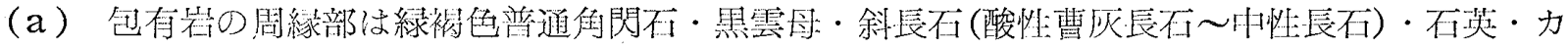
リ長不・磁鉄鉱，および少量の燐不不からなつていて，黑雲楣角閃不不英モンゾ二岩質細粒閃緑岩で ある。等精組織がかなりよく発達している。角閃不は普通 0.5 1 $\mathrm{mm}$ の長さで，部分的に黒雲母

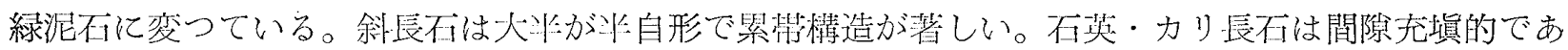

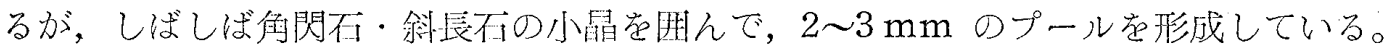

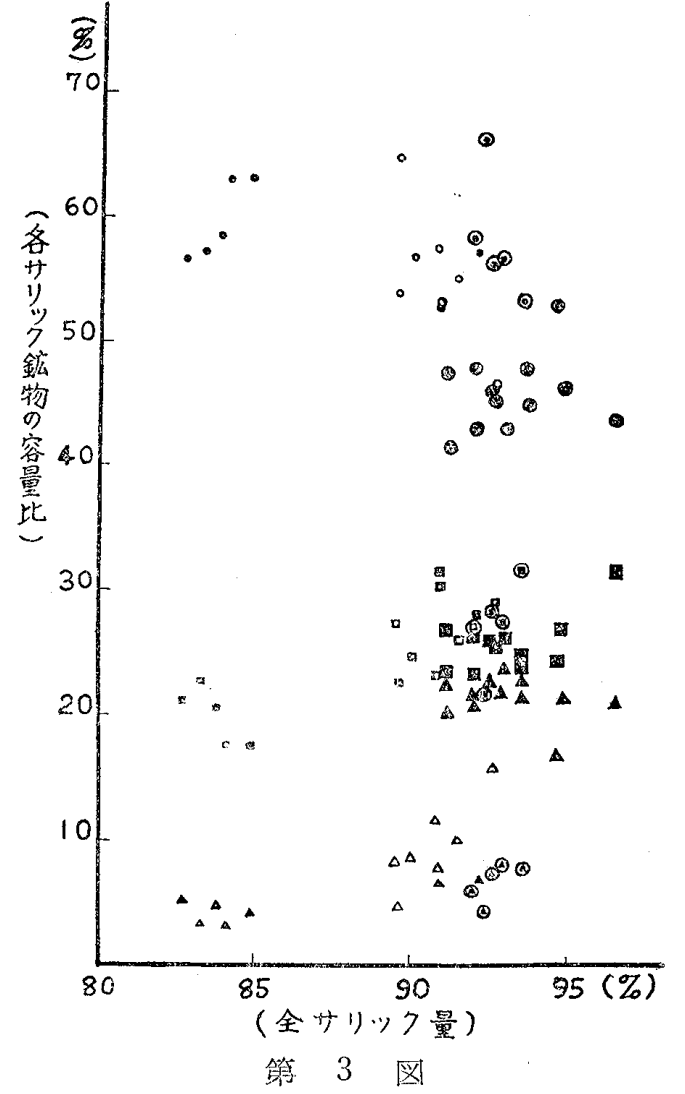

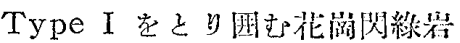

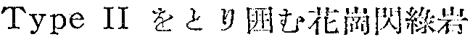

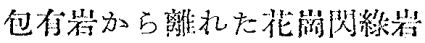

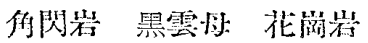

(b) 包有岩の中央部が周緑部よりも優白質

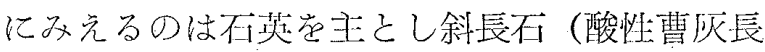
石〜情長不）・解閃不・黑雲母などの小結晶 からなるプールが䁌加している（したがつて粗 粒になつている) ためである。また，中央部で は長柱状 (数 $\mathrm{mm} \sim 1 \mathrm{~cm}$ ) で不規則な外形の角 閃不・黑雲母点住している。比較的大きい包

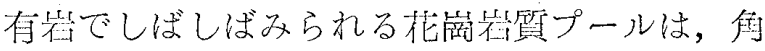
閃不・黑雲母花崗閃緑坏質で，斜長不の班状変 晶为みられる。

Type II の周縁部が縕䊀なのは，花崗宕化作 用に少立つた熱変成标構成時期の組織がまだ充 分生長せずに残存しているためと考光られる。 また，中以部の針状の有色鉱物は花崗化過程で

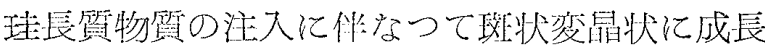
したものであろう。その際，一種の変成分化が 行方れ，包有皆内部の優向化とともに，一部の 鉄洁土物貿は周緣部に移動集積したことも考光 られる。

\section{3. 塩基性包有岩の変成過程の考察}

こてでは成分鉱物の容量比を参照しながら，

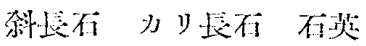

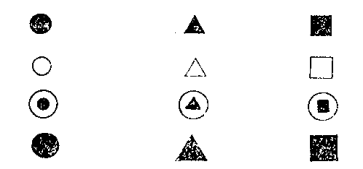

初めは 2 つの型の包有岩を别々に，次いで花崗

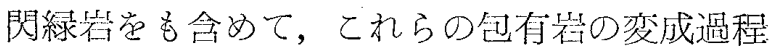
崖考元てみよう。

2つの型の包有岩を鉱物谷量比についてそのちがい走みると, type II は type I より娄斜辰不成 分で約. 2〜3\%，不英成分で約 3〜4\% 富んでいるが，全 mafic 量は約 4〜5\% 乏しい（第 4-a，

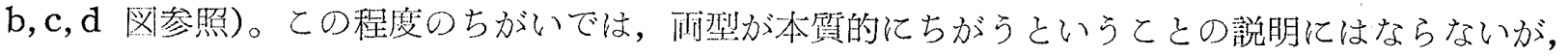
筆者は野外および室队研究の結果を総合して，下に述べるように，ての栭型がそれぞれ别な原岩から 由来しているとみたうが缒当である，と考えている。

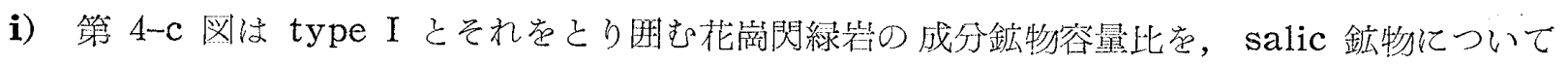




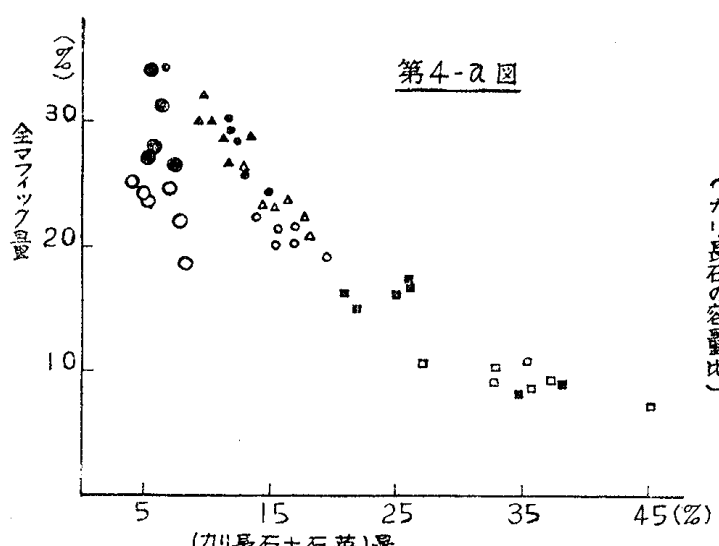

(力少长石十石英) 虽
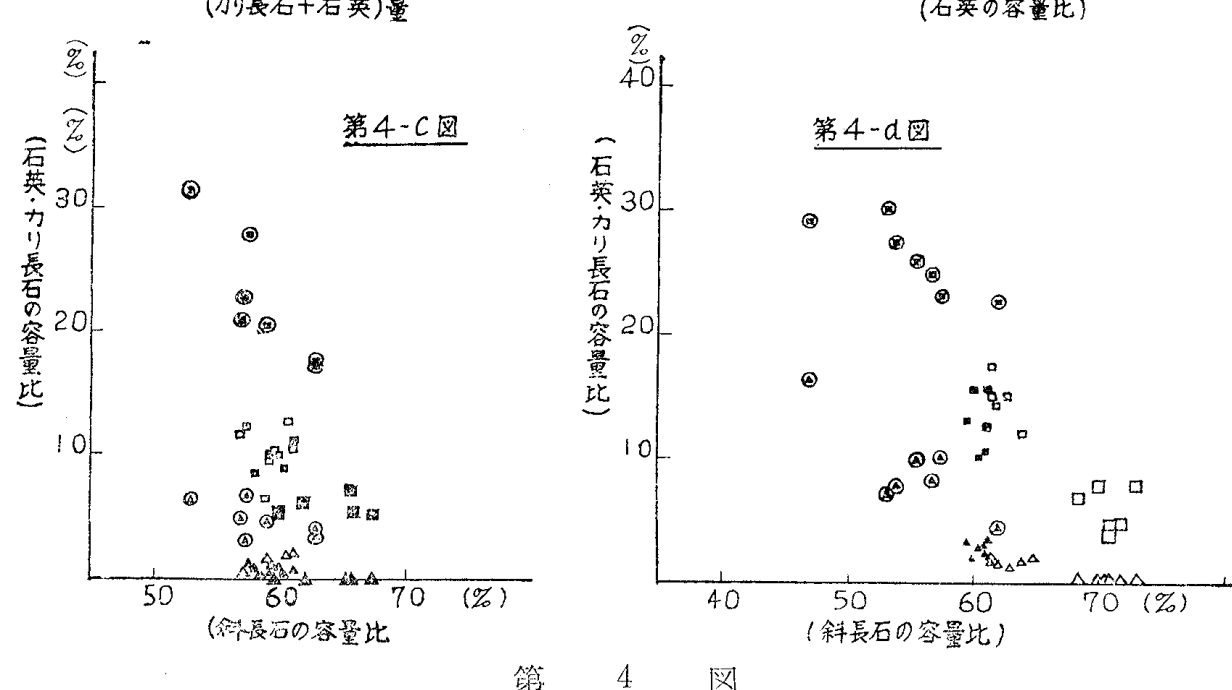

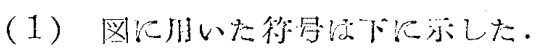

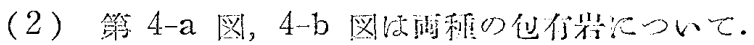

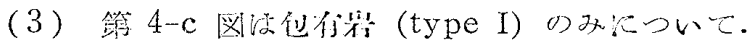

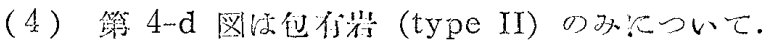

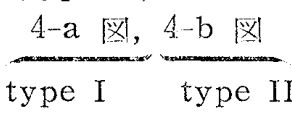

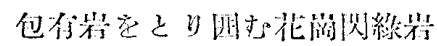

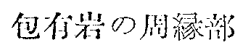

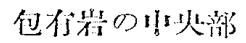
玢赫

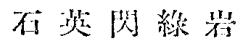

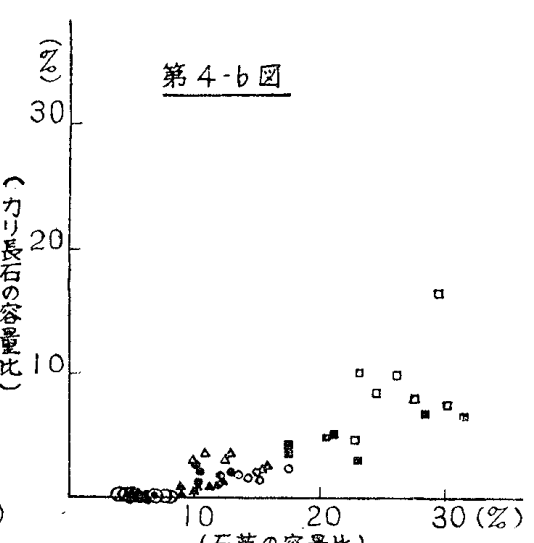

(石英の容量比) $(\%)$

s.

敦化したものである。

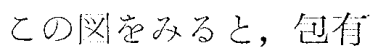

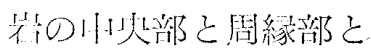
定谷量比加ら区别守る ことはで童子い。岡し ことは籍 4-d 情以外 の为汃らもいわ教るて とである。

IVの2。i）で边べ たように type I は閃

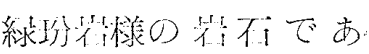
る。家たtype I の浐 状からみて, type Iが

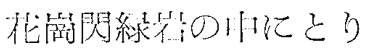
こまれてから，あ卖り 長い経路起栘動しては いないらしいというと とが落觉られる。术地

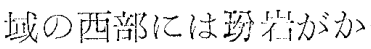
实り压人発澾している ので，乙れ范 type I の原倠と考えれば，以

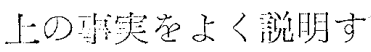
るととができる。

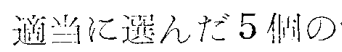

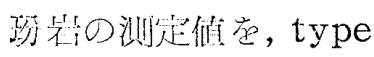
I と比较するたるに， 符 4-a $4-\mathrm{b} \cdot 4-\mathrm{c}$ 甽 に六した。こ礼らに ると，玢背证 type I に比べて斜上不成分に

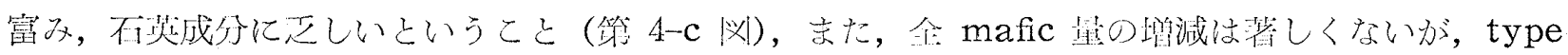

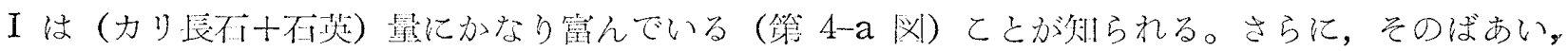

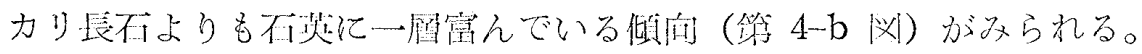

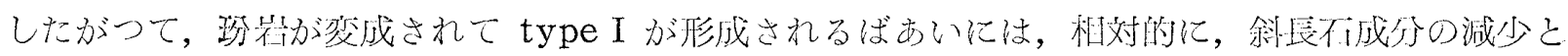

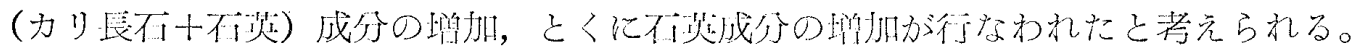

ii）Type II のばあいには，第 4-a 兴にみられるように type Iに比べて，罣かながら山以部が

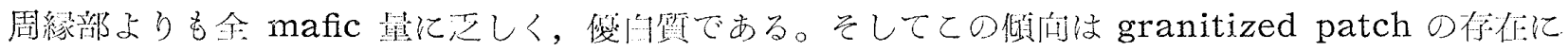
よつて需に顕者にされている。

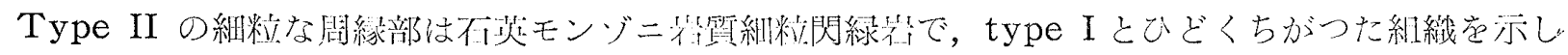


ているととや, type II が熱変成石英閃緑岩と花崗閃緑炭との接触部（锥音崎）附近でのみ見出ださ れるととなどから，筆者は type II の原岩は，type I とは異なつて，石英閃緑宕であろうと解瀵 した。

そてで本地域の石英閃緑岩から 6 個の標本を選び，第 4-a・4-b・4-d 図にその測定值を記入した。 第 4-a 四抢よび 第 4-d 図から知られるととは，石英閃緑吡と type II 苨比較すると，全 mafic 量 はほとんどちがわず，斜長石成分は後者が著しく少ないが，そのかわり石英成分には著しく富み，力 リ長石成分には僅かに富んでいる。

そこで, 石英閃緑岩が変成されて type II が形成されるばあいには，斜長石成分の著しい減少と， 石英成分の著しい増加㧍よびカリ長石成分の僅かな増加が考光られる。

iii）包有岩から $50 \mathrm{~cm}$ 以上離れている（包有岩の影響を受けていない）花崗閃緑岩の測定值と，

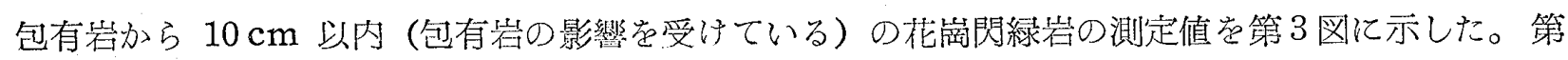

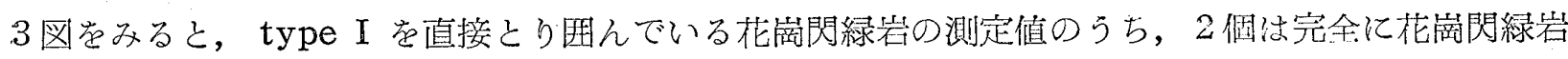

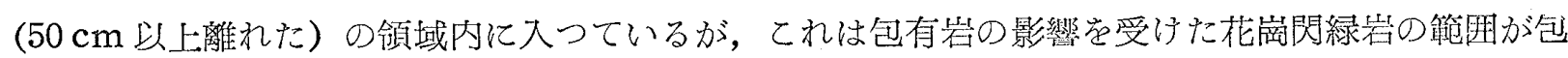
有岩から $10 \mathrm{~cm}$ よりもずつと狭いてともある，ということ走していると考㝋られる。

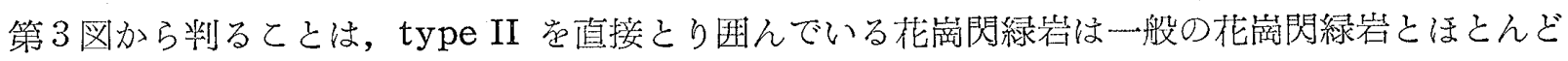
同じ成分からなつているのに対して，type I をとり囲む花南閃緑坛は一般の花崗閃緑宕よりも全 salic 量泛しく, 全 mafic 量に富んでいるということである。また, ての全 salic 量のうち, 斜 長石成分はほとんどちがわないが，type I をとり囲む花崗閃緑岩はわずかにカリ長石成分就よ゙石 英成分に乏しいととがわかる。これらのとと学総括して，筆者は次のように解釈した。

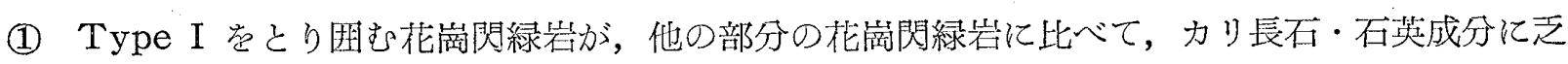
しく（斜長石成分や）全 mafic 量に富んでいるのは，type I の包有岩がそれをとり囲んでいる花 䒽閃緑玨に与えた一種の basification ひ結果である。

(2) Type IIæとり囲む花崗閃緑岩と他の部分の花崗閃緑宕とが，ほとんど同じ鉱物容量比を示し

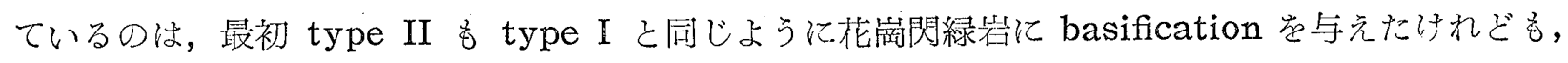
後に述べるように，てのばあいは貫入運動による混和のため，包有岩をとり囲んだ部分も，その他の 部分も均一な成分になつたものであろう。

iv）以上 IV・3で述べてきたととに，IV・1 および 2 で述べたととも含めて，塩基性包有岩が 作られた過程を考えてみよう。

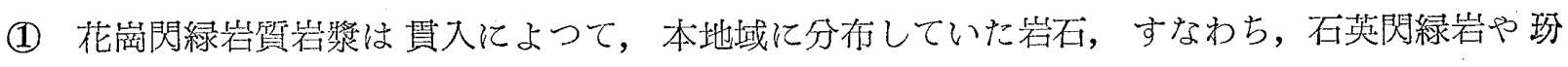
岩, 石英斑岩などせ，ルーフ・ペンダント様に保つたり，あるいは包有岩としてその中にとり込んだ りした。

(2) 包有碞の大部分を占める type I は，おそらく，花閭緑岩質岩漿が貫入してきた際に玢岩が 岩槳中にとりてまれて変成されたものである。今まで述べてきた type I の産状や顕微鏡的な多くの 特徽, さらに, それが花崗閃緑若に与えている一種の basification なぞの現象は, 玢岩が据漿中に とりとまれて，しかもとりてまれた位置からあまり移動せずに（in situ に）あまり著しくない花 崗岩化作用（一部の mafic elements の除去と salic elements の附加）蒙つたととを示してい る。とくに石英成分はとの花崗岩化作用で優勢に働いたと考えられる。

(3) Type II の産状が観音崎に限られているととや,その形が楕円体状で角ばつたものがほとんど みられないととなどはIV・1 で述べたが，ての2つの点にはとくに注意せねばならない。

観音崎の石英閃緑岩は他の地点の石英閃緑岩よりも, 一層強度の熱変成作用を受けている。Type II 
はここの不英閃緑岩に接している花菵閃緑岩の中にだけ含まれているのである。かかる type II の 産状や，IV・2，3 で迅べた種々の特性から，筆者は，type II は花菵閃緑岩質岩漿が貫入する際に，

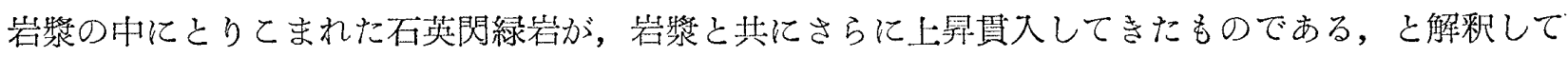
いる。そのために, type II は type I よりもはげしい変成交代作用を受け，しばしば花率岩質 な granitized patch を含むようになつたのであろう。

\section{V. 花崗岩質“偽捕獲岩”}

\section{1. “偽捕獲岩”之は?}

花崗岩化作用に件なう色々な feature については，てれまで多くの研究者によつて指摘されてき た。ここで述べる花崗岩質 “偽捕獲岩”も花崗岩化作用に俳なう feature の1つである。

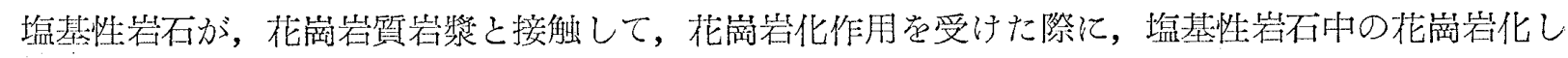
た部分が，まだ花崗㓪化の進まない部分と比較的シャープな境界をもつととは，かなり普通にみられ る。それで，たまたま，ての花崗岩化した部分が円磁ないし角磷状の形觉していると，一見塩基性岩 石中にとりとまれた花䒽䇹質捕獲岩のように解されることがある。このばあい，てれらの捕獲岩様の 花南岩の成因が正しく把握されていないと，相互倿触する雨岩体の貫入前後関係が全く逆獬釈さ: れる危険性が大きいわけで，とくに留甞する必要がある。笵者はかかるもの花葻岩質 “偽捕獲岩”

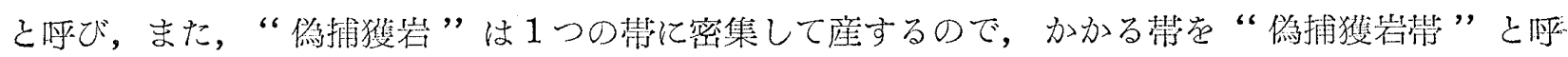
んだ。

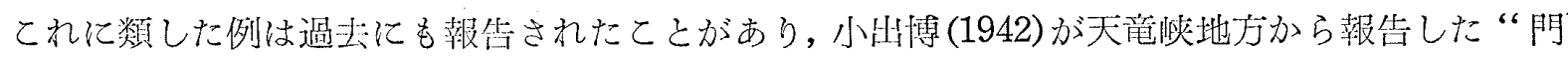

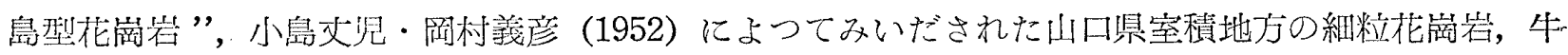
来正夫（1948）の報告した福島県田村郡船引町地方の細粒斜長花峝岩（trondhjemite）質宕石など

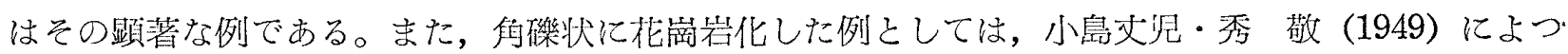
て岡山県小田郡陶山村の熱変成岩中の syenitic apliteの形成のし方か解析されている。しかし，山 除地方の花厥岩ではまだ例を知らない。

\section{2. 花崗岩質偽捕獲岩の産状}

すでに述べたように，花崗岩質偽捕獲岩は観音崎北端で，熱変成不英閃緑䇹と解閃石黑雲母花溯岩 との接触部において，また，一部は角閃不黑雲母花菵閃緑硈との接触部において，石英閃緑岩の縁边

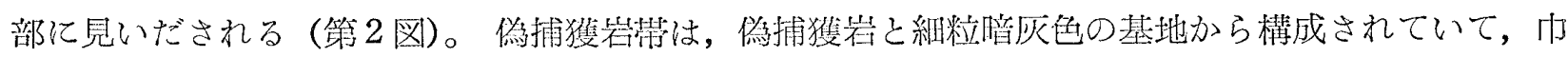

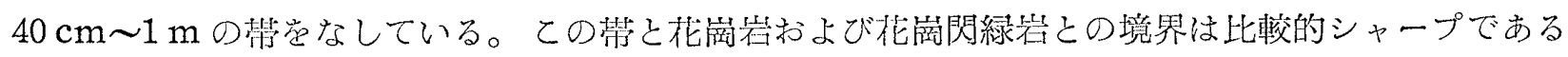
が，熱変成石英閃緑岩には漱移的で境界がはつきりしない（第 9-a 図および第 9-b 図）。偽捕獲岩

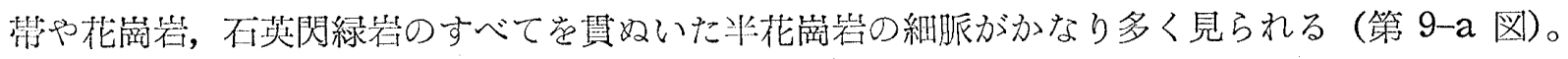

佣捕獲岩は，一般にピンク色に風化していて，直柊 $2 \mathrm{~mm} \sim 3 \mathrm{~cm}$ が普通で，小さいものはほとん ぞ石英のみからできているが，大きいもの化耑岩様になつているのが肉眼でも観察される。てれら は全く不規則に散在しているが，大きくみると，熱変成不英閃緑吡体の内側に向かつて偽捕獲岩が小 さくなつてゆきついには游減している（第 9-a 四）。

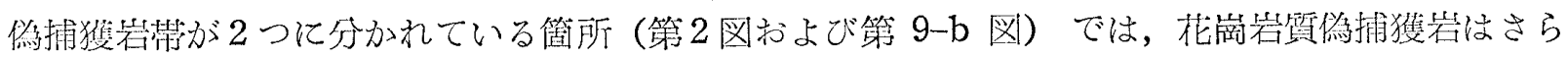
に大きく成長し，かつ，密集していて，細粒暗灰色な基地は著しくせばめられ，肉眼的にも花崗岩に 濑移している。乙ては花崗岩化作用が一層激しく行われた場所である。

\section{3. 偽捕獲岩帯および周囲の岩石の変成現象}

偽捕獲岩は著しく不均質なので，普通の岩石薄片の範囲で容量分析をおてなつてもあまり意味がな: 
ふので谷量比蓬求めなかつた。

\section{i）熱変成石英閃緑岩の縁辺部}

熱変成不英閃緑岩は黑雲是・角閃不・不英・斜長石（曹灭長石）からなつていて，乙れらの構成鉱

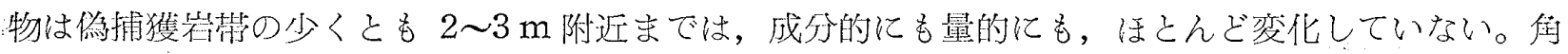
閃不は緑色ないし緑褐色の普通角関不で，部分的に淡色になつたり，また，黒雲昌として丽絬晶した

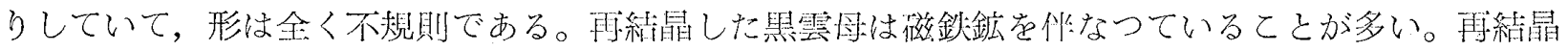
作用は斜長不よりも角閃不に扔いて著しい。偽捕獲岩带に近く 2 3 m 以内では，再結鼠した角閃不

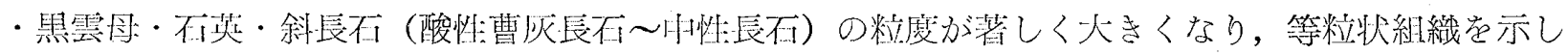

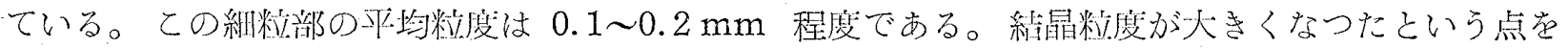
除けば，乙の部分の特性は傦捕獲衃䄍からさらに離れた部分の特性と翌わらない。てのようにして熱

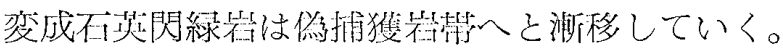

\section{ii）偽捕獲岩帯}

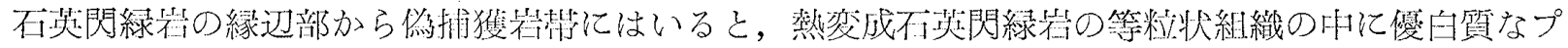

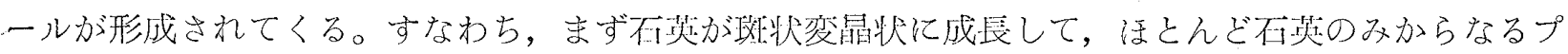

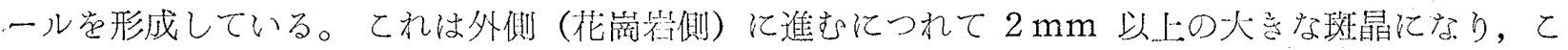

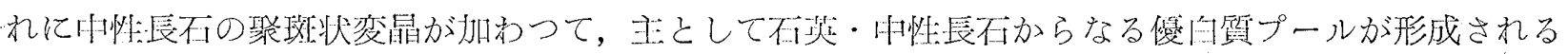

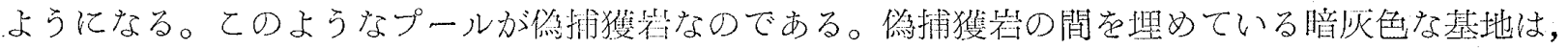
上にのべたように，等䊀状組織走示している緑褐色普通角閃不・黑雲母・不等・惺長不からなつて

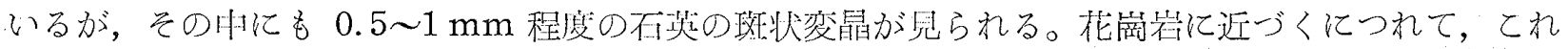

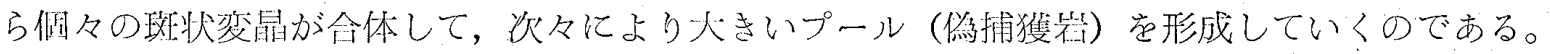

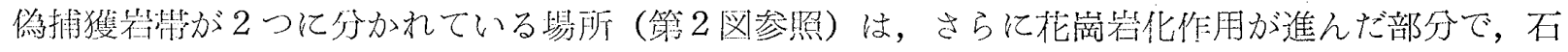

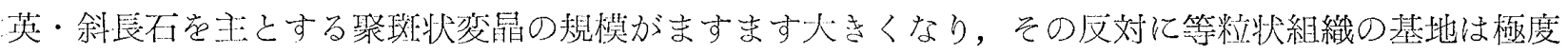

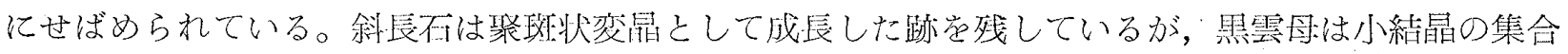

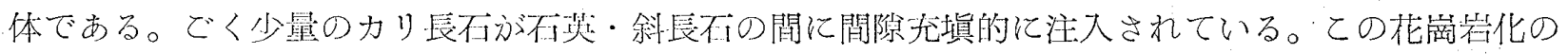
最も進んだ部分は，かくして花崗岩へと移化している。

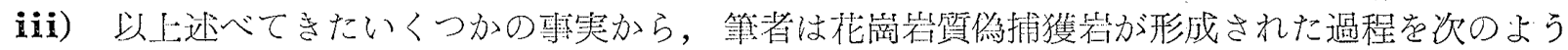
に解釉している。

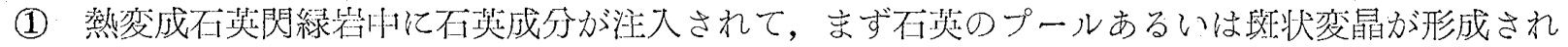
た。

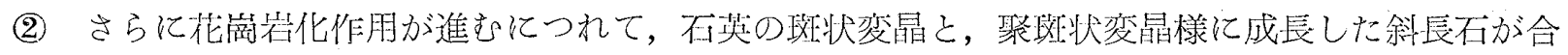
して，不笑と斜長石を主とする花崗碞質偽拥獲岩が形成された。

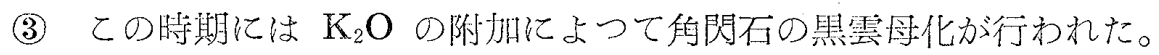

(4)さらに花㖾岩化作用が進んだ部分では偽捕獲岩が著しく密集していて，それにカリ長石が機械 的に注入され，基地住ついに全く消滅して，花崗㧵様の皆石になつた。

\section{VI. ま と め}

i）岡見梁成岩類の主体点なしている花厥閃緑岩は，その中に 2 種の塩基性包有岩（type I type II) 崖含んでいる。また，観音崎の爇変成石英閃緑岩の縁辺部では，花崗岩および花崗閃緑岩 による強い花菵宕化作用の結果，花崗岩覧偽诚獲岩が形成されている。

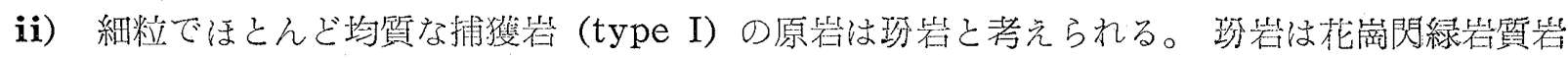



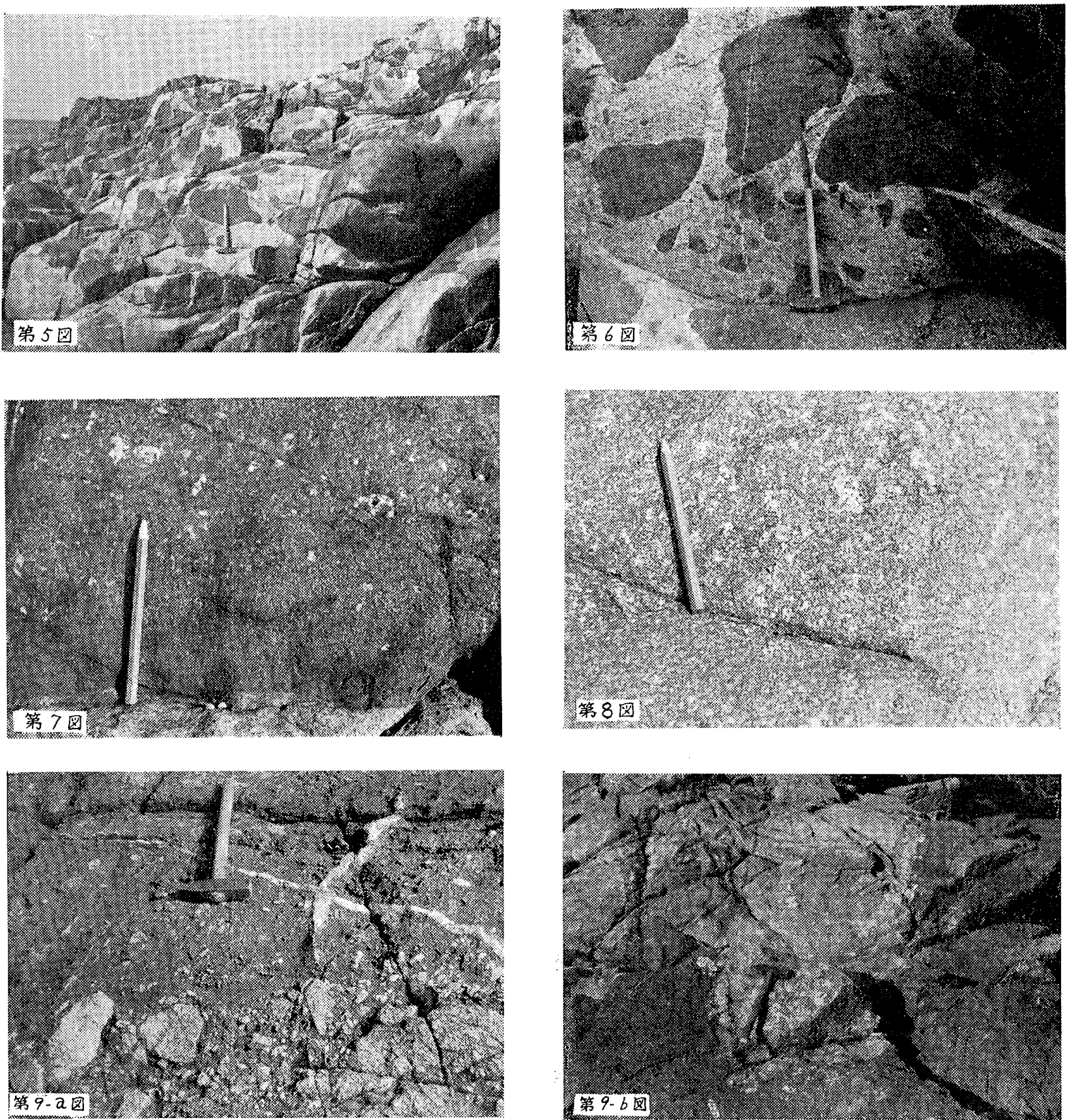

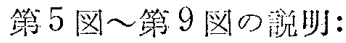

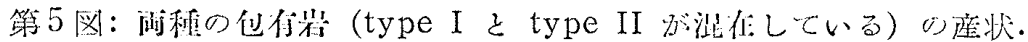

第6 図: type I の他份少の屡状。

第 7 図: type I の仙仍光に見以礼る granitized patch.

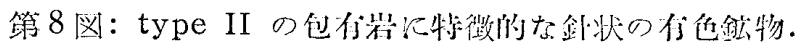

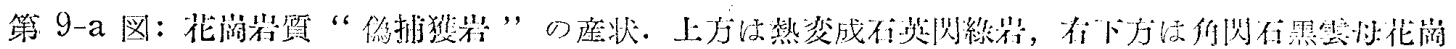
岩.

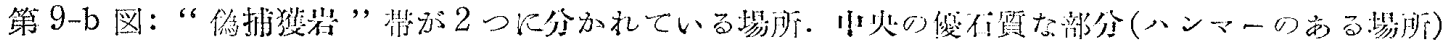

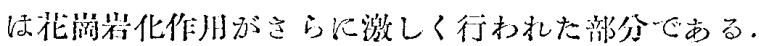




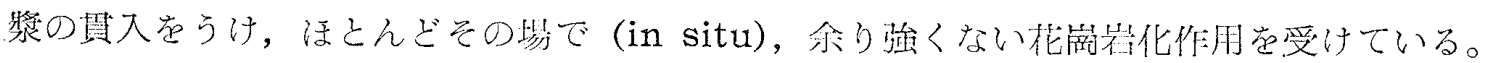

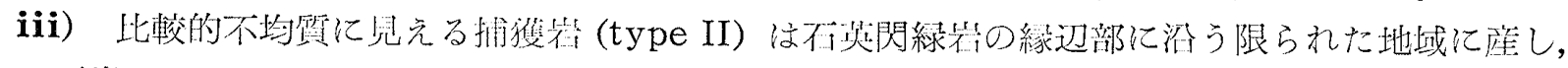

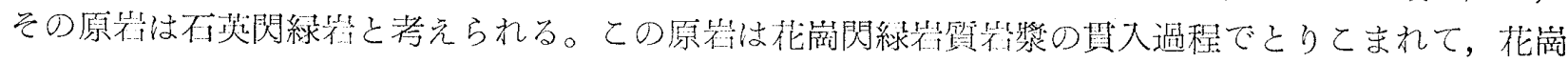

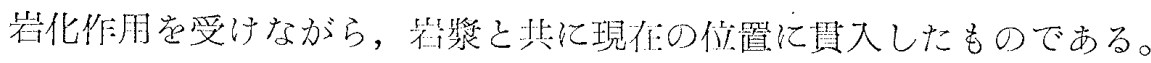

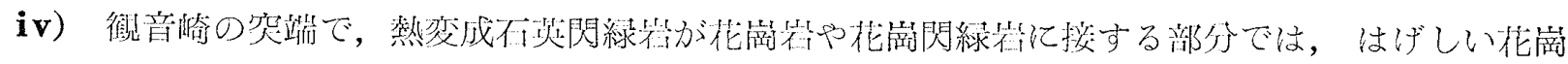

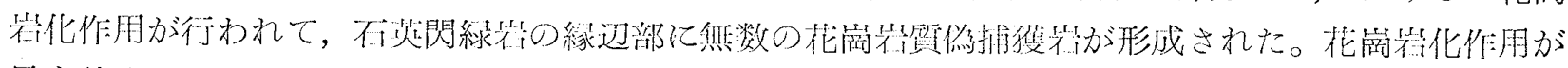

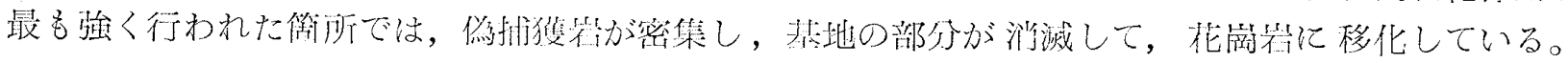

\section{引用 交 献}

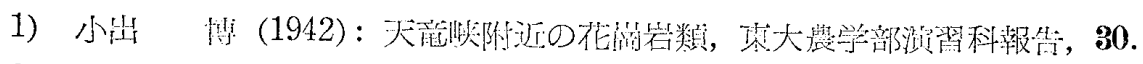

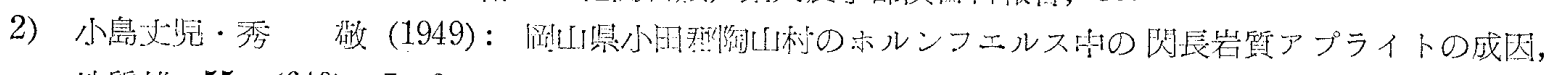

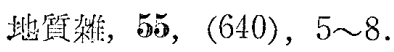

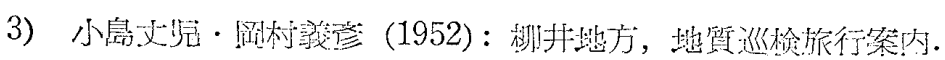

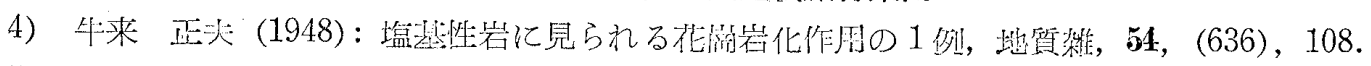

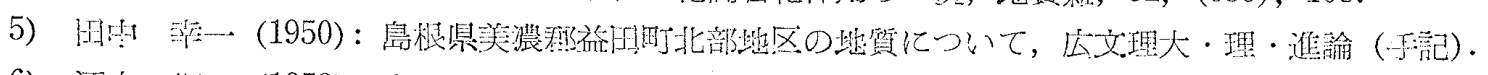

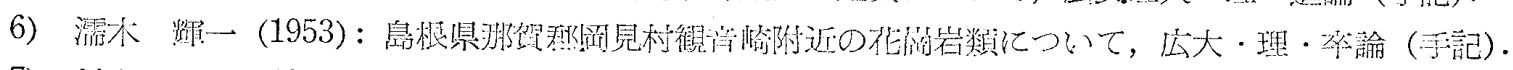

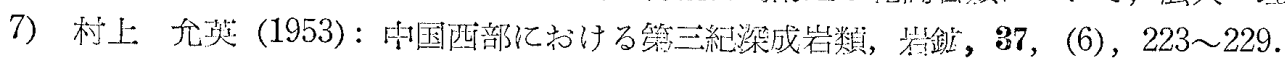

